\title{
Strategi Mengurangi Stigma Penyakit Kusta di Komunitas
}

\author{
Koko Wahyu $\mathbf{T}^{1}$, Junaiti Sahar ${ }^{2}$ \\ ${ }^{1}$ Magister Keperawatan, Universitas Indonesia \\ ${ }^{2}$ Dosen Keperawatan, Universitas Indonesia \\ *Email: kokowahyu01@gmail.com
}

\begin{abstract}
Background: The impact of the stigma caused people with leprosy not only suffer physically but also psychologically because they were isolated and ignored by family members and the surrounding community. Aims this study is to describe strategy to decrease stigma for leprae patient. Methods: The type of research design included in the literature review. The studies will be reviewed in English using qualitative, quantitative, and mixed methods. Searches were carried out using Science direct, PubMed (Medline), Google Search and Proquest with keywords for each variable. Keywords in leprosy search, AND (Stigma or discrimination) AND (Intervention or IEC or counseling). Results: The stigma is explained in five categories, namely the integration of leprosy services into health care, communication, information and education programs, socio-economic rehabilitation, change in name of leprosy, and counseling. Conclusion: The interventions carried out provide at least evidence of success in efforts to deal with stigma with various strategies, namely the integration of leprosy programs into health care, IEC and SER interventions.
\end{abstract}

Keywords: leprosy, society, stigma

\section{PENDAHULUAN}

Kusta masih ada di berbagai negara dan wilayah endemik termasuk India, Brazil dan Indonesia. Survei WHO tahun 2016 menetapkan target eliminasi kusta yang tertuang dalam SDGs 2016-2020 yaitu 1/1.000.000 populasi. Kasus kusta secara global tahun 2016 berjumlah 212.000 kasus dan tahun 2017 terjadi penurunan sebesar 192.713 kasus (WHO, 2018).

Banyak masyarakat yang menderita penyakit kusta selama puluhan tahun, dimana berbagai aspek menjadi permasalahan termasuk pemanfaatan dalam akses fasilitas kesehatan, keterlambatan dalam diagnosis serta manajemen pengobatan yang belum optimal. Ketika pengobatan diberikan pada tahap awal pajanan, penyakit kusta segera dapat disembuhkan, namun terlepas dari manfaat pengobatan tersebut kusta masih menjadi salah satu penyakit yang membawa dampak paling ditakuti, disalah pahami, dan menjadi stigma di masyarakat (Marahatta et al., 2018). Dampak dari stigma tersebut menyebabkan orang-orang dengan kusta tidak hanya menderita secara fisik tetapi juga psikologis karena dikucilkan dan diabaikan oleh anggota keluarga dan masyarakat sekitar (Ballering, 2017).

Stigma yang ditujukan kepada penderita kusta menyebabkan seseorang mengalami frustasi, bahkan upaya bunuh diri dari orang dengan kusta (ODK). Masyarakat telah menstigmatisasi orang yang terkena kusta sejak zaman kuno. Hal itu diwujudkan dalam berbagai bentuk, mulai dari ciri - ciri pasien kusta dengan pakaian khusus atau dengan membunyikan lonceng ketika mendekati orang lain dan pemisahan secara paksa untuk pengemis dalam lingkungan tempat tinggal (Weiss, 2016). Pemisahan klien kusta dilakukan sejak abad ke - 13 ketika kejadian kusta pada perang salib. Di samping itu pengobatan dan perawatan 
pasien kusta yang terpisah terjadi di pelayanan kesehatan. Pengobatan Dapson pada tahun 1940, terjadi perubahan dalam pemberian pelayanan kesehatan. Tahun 1982, Organisasi Kesehatan Dunia (WHO) menyatakan bahwa kusta dapat disembuhkan, meskipun terjadi pemisahan layanan kesehatan dan stigma masih tersebar luas di seluruh masyarakat dunia.

Ketika didiagnosis dengan kusta, klien mencoba menyembunyikan penyakitnya, misalnya dengan mencari perawatan agak jauh dari rumah dengan tujuan untuk menghindari persepsi negatif, serta tidak berkomunikasi dengan anggota masyarakat. Selain isolasi diri yang dilakukan oleh klien kusta, anggota masyarakat juga bersikap negatif dengan menghindari, memaksa pergi, membicarakan dan menolak untuk pergi bersama dengan alat transportasi umum (Andriani \& Bakhtiar, 2015).

Perilaku tersebut selain berdampak negatif pada fisik, juga berdampak status psikologis dan sosial ekonomi orang dengan kusta. Dampak psikologis bagi klien akan menderita tekanan mental dan kecemasan yang mengarah pada depresi bahkan sampai dengan bunuh diri dan dampak pada status ekonomi mereka menurun, terjadi penolakan untuk menikah dan pendidikan yang tidak tuntas (Chaptini, Marshman, \& Centre, 2015).

Berdasarkan dampak yang ditimbulkan, untuk mencegah stigma dan mengurangi penderitaan individu dan keluarga klien dengan kusta, maka diperlukan intervensi yang efektif. Studi literatur ini bertujuan untuk mengidentifikasi intervensi yang telah digunakan untuk mengurangi stigma dan menilai tingkat keberhasilan nya. Hasil ini diharapkan dapat bermanfaat bagi tenaga kesehatan dan profesional lainnya yang ingin mengembangkan intervensi untuk mengatasi stigma terkait penyakit kusta.

\section{METODE PENELITIAN}

Jenis desain penelitian yang dimasukkan dalam literature review. Penelusuran dilakukan dengan menggunakan Science direct, PubMed (Medline), Google Search dan Proquest dengan kata kunci setiap variable. Kata kunci dalam pencarian leprosy, AND (Stigma atau diskriminasi) DAN (Intervensi atau IEC atau konseling). Pencarian dibatasi dari tahun 2010-2018 yang dapat diakses full text dalam format pdf. Artikel yang ditemukan dari masingmasing pencarian dalam bahasa inggris dan Indonesia yang kemudian dilakukan pembacaan secara cermat dan mengambil intisari dari penelitian tersebut dan selanjutnya hasil pencarian disajikan dalam bentuk naratif.

Peneliti telah membaca 20 literatur, terdapat 3 paper dan 2 literatur sama yang dihapus dan menjadi 15 paper, 10 dipilih pada skrining abstrak dan 5 setelah membaca makalah lengkap; akhirnya, 15 dimasukkan dalam ulasan ini. Makalah termasuk ditulis antara tahun 2010 dan 2018. Temuan disajikan dalam bentuk naratif. Intervensi dilaksanakan untuk mengurangi kusta. 


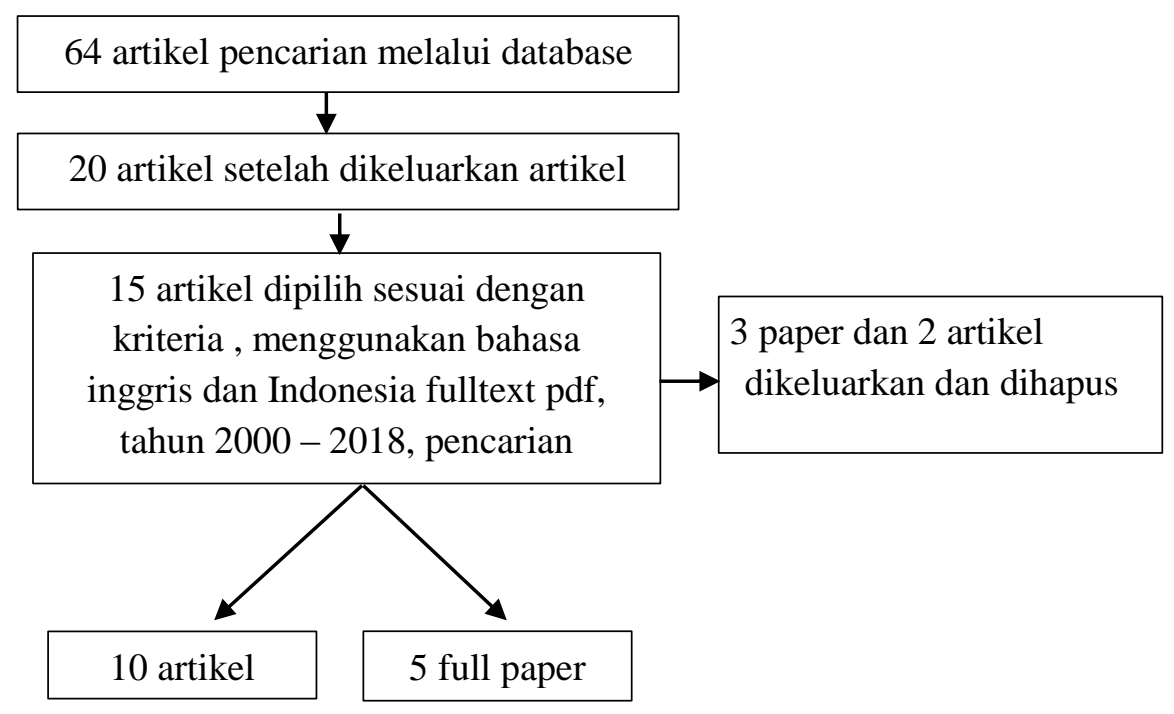

Gambar 1. Flow diagram cara pencarian literatur

HASIL PENELITIAN

Strategi dalam mengurangi stigma dijelaskan dalam lima intervensi yaitu integrasi layanan kusta dalam perawatan kesehatan secara umum, program komunikasi, informasi dan Edukasi, rehabilitasi sosial ekonomi, perubahan nama penyakit kusta dan konseling.

\section{Layanan Terintegrasi Perawatan Kusta}

Pada banyak negara, layanan kusta telah terintegrasi ke dalam layanan kesehatan yang bertujuan untuk memberikan perawatan bagi pasien kusta di sekitar lingkungan tempat tinggal dan untuk mengurangi perbedaan antara penderita kusta dan penderita penyakit lainnya. Studi penelitian yang dilakukan Muthuvel, Govindarajulu, \& Isaakidis, (2017) di Maharashtra, India membandingkan tingkat stigma antara area pendekatan dengan perawatan terintegrasi dan perawatan yang langsung diberikan pada pasien kusta.
Hasilnya ditemukan bahwa ada sedikit stigmatisasi diri antara pasien kusta dan kurangnya stigma sosial di masyarakat apabila pasien kusta diintegrasikan dalam layanan kesehatan. Bahkan pasien kusta dan keluarga mampu terlibat dalam pengambilan keputusan dengan pendekatan terpadu, sementara perawatan yang langsung diberikan pada pasien kusta, tidak ada komunikasi.

Perawatan kusta di Negara Thailand diintegrasikan ke dalam sistem perawatan kesehatan sejak tahun 1973 sampai tahun 1998. Namun laporan perkembangan dan evaluasi dalam rencana eliminasi kusta (1994 - 1996) tidak menyebutkan apakah stigma terkait kusta telah menurun, meskipun fakta membuktikan bahwa orang dengan kusta dapat hidup "normal" di komunitas (Sermrittirong, et.,al.,2015).

\section{Komunikasi, Informasi, dan Edukasi (KIE)}

KIE merupakan pendekatan yang digunakan untuk meningkatkan kesadaran masyarakat tentang kusta yang bertujuan 
untuk mengurangi stigma dan untuk membantu menemukan kasus penularan kusta sebelum terjadi kecacatan (Rao \& Press, 2015). Penyuluhan di masyarakat yang dilakukan di Negara Srilangka adalah contoh dari intervensi KIE yang berhasil sejak tahun 1990. Intervensi tersebut dengan menemukan kasus orang dengan lesi kulit untuk segera didiagnosis dan mencegah sikap negatif masyarakat terhadap orang dengan kusta. Tenaga kesehatan dilatih untuk mendiagnosis kusta dan melakukan perawatan secara intensif (Wijesinghe \& Wijesinghe, 2013).

Informasi kesehatan dilakukan dengan media yang berbeda, dengan memberitahukan bahwa penyakit kusta adalah penyakit normal yang dapat disembuhkan dan tidak menyebabkan kecacatan jika dilakukan perawatan secara dini. Konten informasi yang akan dibuat, terlebih dahulu dilakukan survei berbasis masyarakat tentang pengetahuan, sikap dan perilaku terkait kusta serta berfokus untuk mengekplorasi persepsi masyarakat tentang kusta. Survei berbasis masyarakat menjelaskan bahwa masyarakat menganggap kusta adalah penyakit sangat menular, tidak dapat disembuhkan dan menakutkan karena menyebabkan ruas jari - jari tangan dan kaki jatuh serta lepas. Informasi yang didapatkan tersebut, digunakan untuk mengembangkan materi KIE yang dibutuhkan. Informasi dalam KIE yang diberikan kurang dari satu tahun tersebut menunjukkan hasil penemuan kasus yang baru terdeteksi sebesar 150\% dengan pelaporan secara dini berdasarkan inisiatif masyarakat (Wijesinghe \& Wijesinghe, 2013).

Informasi dalam KIE selain menjelaskan penyakit kusta, juga mempromosikan pengobatan secara dini untuk tujuan mengurangi stigma di Uttar Pradesh, Madhya Pradesh, Orissa, Bihar dan Benggala Barat India. Intervensi dalam penyebaran informasi dengan menggunakan televisi, radio, teater, video dan acara publik lainnya. Hasil dari intervensi menjelaskan bahwa proporsi orang yang mengatakan tidak akan duduk di sebelah pasien kusta turun dari $44 \%$ menjadi $27 \%$, demikian pula proporsi yang tidak mau makan makanan yang disiapkan oleh pasien kusta dari $68 \%$ menjadi $50 \%$, serta proporsi yang percaya bahwa kusta yang disebabkan oleh perbuatan dosa dalam kehidupan sebelumnya turun dari $37 \%$ menjadi $12 \%$ (Nursanti Anwar, 2019).

Penelitian yang dilakukan di Bangladesh membandingkan antara kelompok yang menerima pendidikan kesehatan tentang kusta dengan kelompok yang belum menerima pendidikan tentang kusta. Hasil menunjukkan bahwa sekitar $75 \%$ tidak akan membeli barang dari penjaga toko yang diketahui menderita kusta dibandingkan dengan $25 \%$ dari kelompok yang telah menerima pendidikan kesehatan (Devang, Patel, \& Godara, 2013).

Terlepas dari hasil positif ini, kegiatan KIE tidak selalu mengubah sikap terhadap kusta yang diinginkan, misal beberapa anak menjadi kurang toleran terhadap kusta setelah sesi pendidikan kesehatan tentang kusta di sekolah di India Selatan. Penelitian lain menunjukkan bahwa peningkatan pengetahuan tentang kemampuan untuk menyembuhkan penyakit tidak mengubah sikap negatif terhadap penderita kusta, dimana ketakutan dengan penyakit kusta membuat sulit mendidik masyarakat tentang penyakit ini. Bahkan tokoh masyarakat menyampaikan bahwa 
perubahan sikap terhadap penyakit kusta sangat sulit dan menjadi hal tabu di masyarakat karena dianggap penyakit yang mengganggu kehidupan sosial (Nitesh Mohan, 2013).

Program Kontrol Kusta di Negara Thailand melakukan kampanye kesehatan di antaranya untuk mendukung eliminasi kusta yang didukung oleh pemerintah kerajaan. Kampanye tersebut berisi tentang MDT dan pengobatan secara gratis yang diharapkan dapat mengakhiri ketakutan masyarakat terhadap kusta dan deteksi kasus secara dini. Kampanye tersebut dilakukan di tingkat nasional, provinsi dan daerah melalui leaflet, televisi, poster, radio, pertunjukkan teater dan majalah. Pemberian honor insentif diberikan untuk penemuan kasus baru dan menyarankan penderita untuk diperiksa dan didiagnosis sedini mungkin. Kegiatan kampanye yang telah dilakukan sebanyak tiga kali, menunjukkan bahwa jumlah kasus yang terdeteksi meningkat sebesar $20 \%$, sementara jumlah kasus yang baru terdeteksi dalam kampanye berikutnya menurun. Kesimpulan tidak ada catatan apakah stigma yang melekat pada kusta telah berubah sebagai akibat telah dilaksanakan kampanye (Sermrittirong, et.,al, 2015).

\section{Rehabilitasi Sosial Ekonomi}

Strategi dalam megurangi stigma kusta dengan fokus pada proses rehabilitasi pasien disabilitas yang melibatkan masyarakat dan kebijakan pemerintah (Sermrittirong \& Brakel, 2015). Cross, Missions dan Way., (2015) mengembangkan program STEP (Stigma Elimination Program) yang berfokus perawatan diri pada klien kusta yang sudah sembuh atau yang masih menjalani perawatan yang diharapkan dapat mengurangi kecacatan. Program STEP berupa pelatihan ketrampilan pada penderita kusta, dan pelatihan untuk membantu dalam menemukan kasus kusta di masyarakat sehingga diharapkan pemberantasan kusta dapat dilakukan secara aktif.

Program SER (social economic rehabilitation) yang dilaksanakan merupakan strategi untuk menghilangkan hambatan antara klien kusta dan masyarakat dengan partisipasi aktif klien yang berfokus pada kemampuan klien dengan pemberdayaan sehingga klien dapat membuat dan mengambil keputusan. Program ini dapat membuka peluang dan dukungan bagi penyandang disabilitas klien kusta dengan memberi bantuan berkelanjutan, perlindungan dan kemitraan yang efektif dengan organisasi lain yang berkontribusi pada kegiatan yang bermanfaat bagi klien kusta (Nirman Bhawan, 2015).

\section{Mengubah Istilah Penyakit Kusta}

Perubahan istilah penyakit kusta telah dilakukan di berbagai Negara, tetapi hal ini belum menunjukkan keefektifannya. Di jepang kusta mempunyai kesan negatif dan menyebabkan diskriminasi dan stigma sosial di masyarakat. Asosiasi pasien dengan kusta "Zen-Ryo-Kyo" di jepang mengubah nama kusta menjadi penyakit Hansen (Hosoda, 2010). Di Negara Brazil pasien penyakit kusta mengalami penolakan dan diskriminasi di lingkungan tempat tinggalnya. Pada tahun 1970 pemerintah melakukan perubahan kusta menjadi "Hanseniasis". Perubahan istilah Hanseniasis dapat membantu mengurangi stigma sehingga perawatan dan manajemen MDT (Multi Drug Therapy) berhasil. Hanseniasis yang terdapat di 
Alkitab mengacu pada penyakit dermatologi yang terpisah dari kusta (Sillo et al., 2016).

\section{Penyuluhan}

Konseling dapat membantu pasien untuk mengatasi permasalahan fisik dan psikologis yang ditimbulkan oleh karena penyakit kusta. Marahatta et al., (2018) dalam studi penelitian di Nepal konseling kelompok untuk orang-orang yang terkena kusta membagi dalam grup yang terdiri dari 5-7 orang bertemu 2 jam selama 5 minggu. Mereka bertemu sebagai orang dewasa tunggal gender atau kelompok anak-anak. Pasien dimasukkan setelah penilaian psikologis di mana mereka telah menunjukkan setidaknya satu berikut ini: pengakuan bahwa rendahnya harga diri mereka disebabkan oleh stigmatisasi, penolakan oleh keluarga, atau merasa sedih tetapi tidak secara klinis tertekan. Peserta didorong untuk membagikan pengalaman hidup mereka dengan anggota kelompok lainnya. Hal ini akan menumbuhkan ikatan antara anggota kelompok ketika mereka mendengar orang lain menceritakan tentang pengalaman menyakitkan mereka sendiri dan bisa saling menghibur.

Anggota kelompok saling belajar untuk memaafkan orang lain yang melukai mereka, dan bersiap pulang untuk mengatasi stigmatisasi yang terdapat di lingkungan masyarakat. Konseling untuk pasien kusta di Thailand hanya dilakukan di beberapa unit kesehatan misal rawat jalan di Organisasi Kusta Nasional, dan di beberapa daerah serta unit kesehatan provinsi. Tidak terdapat bukti yang menunjukkan sejauh mana konseling dapat membantu mengurangi stigmatisasi (Adhikari, Shrestha, Kaehler \& Raut, 2015).

\section{PEMBAHASAN}

Dampak stigma terhadap efektifitas program pengendalian kusta semakin meningkat dalam upaya untuk menangani stigma. Integrasi program kusta ke dalam sistem perawatan kesehatan merupakan bagian penting dalam strategi WHO untuk menghilangkan kusta. Strategi ini dianggap sebagai pendekatan untuk mempromosikan aksesibilitas layanan kusta untuk orang yang terkena dampak dan mengurangi stigma kusta. Namun tidak semua Negara menerapkan pelayanan terintegrasi kusta, misal tingkat stigma tidak disebutkan dalam laporan evaluasi program kusta di Thailand (Sermrittirong, et.,al, 2015).

Penerapan di India, investigasi hasil dalam hal stigma telah dilakukan, hasilnya terdapat sedikit stigmatisasi diri antara pasien kusta dan stigma sosial yang berkurang di masyarakat dengan pendekatan terintegrasi daripada pendekatan secara langsung. Sedangkan dalam hal pendekatan kesehatan jiwa, sejauh ini tidak ada bukti mengenai efek integrasi terhadap pengurangan stigma (Muthuvel et al., 2017). Namun penelitian Mwape di Zambia menjeaskan bahwa penyedia pelayanan perawatan harus mengintegrasikan penyakit mental (jiwa) ke dalam perawatan kesehatan primer yang secara bertahap mengubah sikap masyarakat ketika mereka melihat bahwa pasien - pasien jiwa dirawat dan sembuh, bukan untuk dihina dan diasingkan (Heijnders, 2015).

KIE merupakan pendekatan yang digunakan untuk meningkatkan kesadaran masyarakat tentang kusta yang bertujuan untuk menemukan kasus secara dini dan mendiagnosis penyakit. Penyuluhan kesehatan yang dilakukan di Negara Srilangka adalah contoh dari intervensi 
KIE yang berhasil. Intervensi yang dilakukan memperomosikan pengobatan MDT (Multi Drug Therapy) dan mengurangi stigmatisasi seperti di India dan Bangladesh (Nirman Bhawan, 2015). Hasilnya sikap akan stigma terhadap orang dengan kusta menurun secara signifikan. Hal ini juga dilakukan di Uttar Pradesh, Madhya Pradesh, Orissa, Bihar dan Benggala Barat India. Hasil dari intervensi menjelaskan bahwa proporsi orang yang mengatakan tidak akan duduk di sebelah pasien kusta turun dari $44 \%$ menjadi $27 \%$, demikian pula proporsi yang tidak mau makan makanan yang disiapkan oleh pasien kusta dari 68\% menjadi 50\%. Di samping itu, proporsi yang percaya bahwa kusta yang disebabkan oleh perbuatan dosa dalam kehidupan sebelumnya turun dari $37 \%$ menjadi $12 \%$.

Penelitian yang dilakukan di Bangladesh membandingkan antara kelompok yang menerima pendidikan kesehatan tentang kusta dengan kelompok yang belum menerima pendidikan tentang kusta. Hasil menunjukkan bahwa sekitar 75\% tidak akan membeli barang dari penjaga toko yang diketahui menderita kusta dibandingkan dengan $25 \%$ dari kelompok yang telah menerima pendidikan kesehatan.

Namun dalam beberapa kasus, kegiatan KIE tidak selalu berhasil merubah sikap terhadap kusta yang diinginkan. Studi penelitian di India Selatan tentang pengobatan kusta tidak merubah sikap negative masyarakat terhadap penderita kusta dikarenakan takut terhadap dampak kusta. Alasan sikap tetap tidak berubah bahwa dalam penelitian ini tidak mengambil kepercayaan yang terdapat di kelompok sasaran, contoh beberapa anak menjadi kurang toleran terhadap kusta setelah sesi pendidikan kesehatan tentang kusta di sekolah di India Selatan. Penelitian lain menunjukkan bahwa peningkatan pengetahuan tentang kemampuan untuk menyembuhkan penyakit tidak mengubah sikap negatif terhadap penderita kusta, dimana ketakutan dengan penyakit kusta membuat sulit mendidik masyarakat tentang penyakit ini. Bahkan tokoh masyarakat menyampaikan bahwa perubahan sikap terhadap penyakit kusta sangat sulit dan menjadi hal tabu di masyarakat karena dianggap penyakit yang mengganggu kehidupan sosial.

Pada negara Srilangka, sebelum melakukan kegiatan KIE, dilakukan survey berbasis masyarakat tentang pengetahuan, sikap dan perilaku tentang kusta dengan diskusi kelompok terfokus untuk mengeksplorasi persepsi tentang kusta. Informasi ini digunakan untuk mengembangkan program KIE yang akan diberikan kepada masyarakat. Menurut Dalal (2006), sikap merupakan sistem interelasi yang kompleks di antara tiga komponen seperti kepercayaan, sikap yang mempengaruhi, dan kecenderungan perilaku. Untuk memahami sikap masyarakat yang buruk, maka penting untuk mempertimbangkan tiga komponen tersebut, yang mana perubahan dalam satu komponen akan mempengaruhi sikap secara keseluruhan.

Faktor keberhasilan lain yang terkait dengan KIE adalah menggabungkan KIE dengan kegiatan lain. Di Srilangka, mereka melatih petugas kesehatan untuk mendiagnosis kusta dan masyarakat untuk membantu melaporkan penemuan kusta apabila menjumpai orang dengan lesi pada kulit yang mencurigakan. Petugas kesehatan meningkatkan pelayanan kesehatan dengan menjalin kerjasama 
dengan Rumah Sakit. Pendekatan tersebut sesuai dengan rekomendasi Bollinger yang mempelajari stigma terkait dengan HIV/AIDs. Bollinger (2002), menyarankan bahwa KIE harus dipertimbangkan sebagai satu komponen intervensi dalam pengurangan stigma untuk mengatasi permasalahan fisik yang ditimbulkan oleh penyakit kusta, masalah komunikasi interpersonal dan adanya keterlibatan masyarakat. Intervensi KIE juga harus disesuaikan dengan area target dan kelompok sasaran. Hal ini sesuai dengan Dijker dan Kooman (2006), yang berpendapat bahwa intervensi yang bertujuan untuk mengurangi stigma seharusnya disesuaikan dengan kondisi, tipe masyarakat dan individu yang terlibat dikarenakan menjadi faktor yang menentukan motivasi untuk mempengaruhi respon seseorang terhadap persepsi yang menyimpang.

SER adalah jenis intervensi lain yang telah dilaksanakan untuk mengurangi stigma. Di Nepal dan Nigeria, SER (Social Economi Rehabilitation) telah berhasil membantu orang yang terkena dampak kusta untuk mendapatkan kembali hak mereka dalam kehidupan di masyarakat. Intervensi ini menghasilkan perubahan sikap yang positif dalam komunitas dan mengurangi stigma orang yang terkena kusta. SER secara efektif juga dapat mengubah sikap masyarakat dan mengurangi stigma yang terkait dengan kondisi kesehatan lainnya seperti orang yang menderita kecacatan. Sikap terhadap orang dengan kecacatan fisik berubah karena perubahan sosial yang menciptakan hubungan yang harmonis dengan menunjukkan sikap saling membantu atau support di antara individu yang sebelumnya dipandang remeh oleh masyarakat.
Mengubah istilah nama penyakit dan konseling adalah strategi lain yang bertujuan untuk mengurangi stigma. Sampai dengan saat ini belum ada laporan terkait efektifitas strategi tersebut.

\section{KESIMPULAN DAN SARAN}

Intervensi yang sudah dilakukan setidaknya memberikan bukti keberhasilan dalam upaya menangani stigma dengan berbagai strategi yaitu integrasi program kusta ke dalam perawatan kesehatan, intervensi KIE dan SER. Intervensi KIE harus didahului dengan studi yang cermat terhadap area target dan populasi dengan mengkombinasikan strategi lain untuk mencapi keberhasilan menangani stigma di masyarakat. Intervensi SER yang telah dilaksanakan berhasil dalam membantu orang yang terkena dampak kusta untuk mendapatkan kembali hak mereka dalam kehidupan di masyarakat dalam hal ini kondisi sosial ekonomi, sehingga untuk meningkatkan berbagai strategi intervensi di atas selain pelaksanaan juga diharapkan ada evaluasi proses untuk menilai seberapa efektif intervensi dalam mengurangi stigma di komunitas serta perlu adanya peran serta dari pemerintah dan stakeholder terkait.

\section{DAFTAR RUJUKAN}

Adhikari, Shrestha, Kaehler, Raut, C. (2015). Community Attitudes towards Leprosy Affected Persons in Pokhara Community Attitudes towards Leprosy Affected Persons in Pokhara Municipality of Western Nepal, (April).

Andriani, Bakhtiar, T. (2015). Faktor Transkultural Persepsi Kesehatan Ibu Dengan Balita ISPA 
Transcultural Factors Towards The Mother Perception Of The Helath Of Toddler Whith. Jurnal Ilmu Keperawatan, 3(1), 1-2. https://doi.org/ISSN : 2338-6371

Ballering. (2017). "People affected by leprosy cannot work like we do . They do less. So why should they live like we do?" Amsterdam University, (February), 4-5.

Bollinger, L. (2002). Stigma: Literature review of general and HIV-related stigma [Internet] [cited2012Sept20].Availablefrom:ht tp://www.stigmaactionnetwork.org/ web/guest/resource?id1/422d0e8e2b776-42cd-9186-4ecb450f39af;

Chaptini, C., Marshman, G., \& Centre, F. M. (2015). Leprosy: a review on elimination, reducing the disease burden , and future research, 307315.

Cross, H., Missions, A. L., \& Way, A. L. M. (2015). The prevention of disability as a consequence of leprosy. American Leprosy, 86, 208-212. https://doi.org/208 03057518/15/064053+05

Devang A Jariwala, Bharat H Patel, Naresh R Godara, S. L. K. (2013). Socio - Demographic and Environmental Correlates of Leprosy: A Hospital Based cases control study. NJCMindia, 4(3), 369-374. https://doi.org/pISSN 09763325 | eISSN 22296816

Dalal AK (2006). Social interventions to moderate discriminatory attitudes: the case of the physically challenged in India.Psychol Health Med ; 11: 374-382.

Dijker JM, Koomen W. A (2006) psychological model of social control and stigmatization: Evolutionary background andpractical implication. Psychol Health Med ; 11: 296-306

Heijnders, M. (2015). The Fight Against Stigma: An Overview of StigmaReduction Strategies and Interventions The fight against stigma An overview of stigma reduction strategies and interventions Miriam Heijnders Correspondence address: Dr. Miriam Heijnders DEV / Health 1090, (March), 1-16. https://doi.org/10.1080/1354850060 $\underline{0595327}$

Hosoda, M. (2010). Hansen' s disease recoverers as agents of change: a case study in Japan, 5-16.

Marahatta, S. B., Amatya, R., Adhikari, S., Id, D. G., Lama, S., Kaehler, N., ... Id, B. A. (2018). Perceived stigma of leprosy among community members and health care providers in Lalitpur district of Nepal: A qualitative study, 1-14. https://doi.org/10.1371/journal.pone. $\underline{0209676}$

Muthuvel, T., Govindarajulu, S., \& Isaakidis, P. (2017). “ I Wasted 3 Years , Thinking It ' $\mathrm{s}$ Not a Problem ": Patient and Health System Delays in Diagnosis of Leprosy in India : A Mixed-Methods 
Study “ I Wasted 3 Years, Thinking It' s Not a Problem ": Patient and Health System Delays in Diagnosis of Leprosy. PLOS Neglected Tropical Diseases, (January), 1-15. https://doi.org/10.1371/journal.pntd. $\underline{0005192}$

Nirman Bhawan. (2015). NLEPguidelines on reduction of stigma and discrimination against persons affected by leprosy (pp. 1-10). New Delhi: Directorate General of Health Services Central Leprosy Division.

Nitesh, Mohan. (2013). Clinico histopathological correlation within the spectrum of hansen's disease: a multicentric study in north india. International Journal of Medical Research \& Health Sciences, 2(4), 887-892.

https://doi.org/10.5958/j.2319$\underline{5886.2 .4 .142}$

Nursanti Anwar, S. (2019). Pengaruh Stigma Masyarakat terhadap Perilaku Pasien Kusta dalam Mencari Pengobatan: Sebuah Tinjauan Sistematis. Jurnal Ners Dan Kebidanan, 173-181. https://doi.org/10.26699/jnk.v6i1.A $\underline{\text { RT.p }}$

Rao, S., \& Press, D. (2015). Perspectives on the impact of stigma in leprosy: strategies to improve access to health care, 49-58.

Sermrittirong, S., Van Brakel, W. H., Kraipui, N., Traithip, S., \& BundersAelen, J. F. (2015). Comparing the perception of community members towards leprosy and tuberculosis stigmatisation. 2015, 54-61. https://doi.org/54 0305$\underline{7518 / 15 / 064053+08}$

Sermrittirong, S., \& Brakel, W. H. Van. (2015). How to reduce stigma in leprosy--a systematic literature review How to reduce stigma in leprosy - a systematic literature review. Research Gate, (May 2014), 149-157. Retrieved from https://www.researchgate.net/public ation/269714390\%0AHow

Sillo, S., Lomax, C., Wildt, G. D. E., Da, M., Fonseca, S., Garcia, N., \& Galan, D. E. A. (2016). A temporal and sociocultural exploration of the stigma experiences of leprosy patients in Brazil, 378-395.

Weiss, M. G. (2016). Stigma and the Social Burden of Neglected Tropical Diseases Stigma and the Social Burden of Neglected Tropical Diseases. PLOS Neglected Tropical Diseases, 2(5), 237. https://doi.org/10.1371/journal.pntd. $\underline{0000237}$

WHO, E. R. (2018). Weekly epidemiological record Relevé épidémiologique hebdomadaire, (35), 445-456.

Wijesinghe, T. S., \& Wijesinghe, P. R. (2013). Original Article Integration of leprosy services into the General Health Service in Sri Lanka: overcoming challenges to implementation in a remote district. Journal of Public Health, 2(March). https://doi.org/10.4103/22243151.11 5846. 